\title{
The Correlation between Perceptions and Compliance in the Use of Personal Protective Equipment of Nurses at RSU Haji Surabaya
}

\section{Hubungan Persepsi dengan Kepatuhan Penggunaan Alat Pelindung Diri pada Perawat di RSU Haji Surabaya}

\author{
Rika Mudrikah Miftakhul Janah, Tri Martiana \\ Department of Occupational Safety and Health, Faculty of Public Health, Universitas Airlangga \\ Campus C Mulyorejo, Surabaya, East Java 60115, Indonesia
}

\begin{abstract}
Introduction: According to previous studies, the level of compliance with the use of personal protective equipment of the nurses at RSU Haji Surabaya was still quite low. Only $17.8 \%$ of the nurses were compliant in using masks, whereas $82.2 \%$ of the nurses were not. Moreover, $57.8 \%$ nurses were compliant in using medical gloves, whereas $42.2 \%$ were not. The purpose of this study is to analyze the relationship between perception and compliance with the use of personal protective equipment of the nurses at at RSU Haji Surabaya. Methods: This study was an observational and cross-sectional study. The population used in this study was the nurses who served in the operating and lung room of at RSU Haji Surabaya. Total sampling technique was used to 33 samples. Moreover, the data were taken by questionnaires and observations. Data analysis was performed by coefficient contingency test by looking at the value of C. Results: The results show that $85.7 \%$ of nurses in the operating room are non-compliant and $33.3 \%$ nurses in the lung room are non- compliant with the use of PPE. The results also showthat the perception variable that has the strongest relationship with compliance is perception of severity $(C=0.312)$. Conclusion: The closest relationship between the two variables are the relationship of compliance of PPE usage with the gender of nurses, and the determination of nurses' perceptions is based on the Health Belief Model approach.
\end{abstract}

Keywords: compliance, nurse, perception, personal protective equipment

\section{ABSTRAK}

Pendahuluan: Berdasarkan penelitian sebelumnya tingkat kepatuhan penggunaan alat pelindung diri pada perawat di salah satu ruangan RSU Haji Surabaya masih tergolong cukup rendah sebesar 17,8\% perawat patuh dan 82.2\% erawat tidak patuh dalam menggunakan masker serta $57,8 \%$ perawat patuh dan $42,2 \%$ tidak patuh dalam menggunakan sarung tangan. Tujuan penelitian ini adalah untuk menganalisis hubungan persepsi dengan kepatuhan penggunaan alat pelindung diri pada perawat di RSU Haji Surabaya. Metode: Penelitian ini merupakan jenis penelitian observasional dengan rancang bangun penelitian cross sectional. Populasi dari penelitian ini yaitu seluruh perawat yang bertugas di instalasi rawat inap ruang bedah dan ruang paru RSU Haji Surabaya dengan jumlah sampel yaitu sebanyak 33 orang yaitu 21 responden dari ruang bedah dan 12 responden dari ruang paru dengan menggunakan teknik total sampling, data diambil dengan penyebaran kuesioner dan melakukan observasi. Analisis data dilakukan dengan uji koefisien kontingensi dengan melihat nilai C. Hasil: Hasil penelitian menunjukkan bahwa sebanyak 85,7\% perawat di ruang bedah kurang patuh dan 33,3\% perawat di ruang paru kurang patuh dalam menggunakan APD. Hasil penelitian juga menunjukkan bahwa variabel persepsi yang memiliki hubungan paling kuat dengan kepatuhan yaitu persepsi keparahan $(C=0,312)$ Simpulan: Hubungan yang paling erat antara dua variabel yaitu hubungan kepatuhan penggunaan APD dengan jenis kelamin perawat dan persepsi perawat terhadap keseriusan berdasarkan pendekatan Health Belief Model.

Kata kunci: alat pelindung diri, kepatuhan, perawat, persepsin

\section{Corresponding Author:}

Rika Mudrikah Miftakhul Janah

Email: rika.mudrikah.miftakhul-2017@fkm.unair. ac.id

Telephone: +6285645102708

\section{INTRODUCTION}

Occupational health and safety is an effort to establish a workplace that is safe, healthy, and free from environmental hazards. It also increases work efficiency and productivity so that the work can be reduced, and the occurrence of accidents or diseases 
can be prevented. The control of occupational health and safety hazards can be done based on 5 stages of a predetermined hazard control hierarchy, namely elimination (eliminating the source of hazards in the workplace), substitution (replacing some potential hazards with a lower risk of danger), engineering control (separation of hazards by workers), administrative control (work procedure), and PPE (Personal Protective Equipment) (Occupational Health and Safety Management Systems, 2007)

Personal protective equipment is a device that has the ability to protect a person by isolating some parts or all of the body from potential hazards at work (Ministry of Manpower and Transmigration of the Republic of Indonesia, 2010). PPE is the last stage of the effort to control the hazard if the control in the previous stage is difficult to do, and the potential risk is still relatively high, so the application of the use of personal protective equipment is highly recommended. The type of personal protective equipment used must also be in accordance with the potential hazards faced by the parts of the body that need to be protected (Uhud et al., 2008).

The use of PPE is required in every workplace, one of which is hospital. A hospital is a workplace that has a high risk to the health and safety of the hospital staff, patients, patient companions, visitors, and the environment. Potential risks of harms in hospitals are physical, biological, chemical, ergonomic and psychosocial harms. Therefore, it is necessary to implement occupational health and safety (OHS) in the hospital environment, one of which is the application of the use of PPE in accordance with the established SOP.

Personal protective equipment usage is one of the OHS programs in hospitals that is associated with the prevention of disease transmission and infection for hospital staff, especially nurses, which starts before the nurse takes an action until after taking an action. Nurses have the risk of contracting a disease or being infected from patients through body fluids, air droplets or airborne transmission, and direct contact. Infection can occur from patients to patients, from patients to nurses, from nurses to nurses, and from nurses to patients.

The results of the study state that the causes of work accidents are due to unsafe behavior (88\%), unsafe action (10\%) and unknown cases (the remaining 2\%) (National Safety Council, 2013). Centers for Disease Control and Prevention (CDC) in 2011 in the United States stated that there were
722,000 cases of nosocomial infections due to noncompliance with PPE. Nosocomial infection is an infection obtained by a person while in a hospital (Rosenstock, 1974).

According to the data from the Labor Social Security Administration Agency in 2015 there were 105,182 cases of workplace accidents, and 2,375 were recorded as cases of serious work accidents resulting in deaths. This happens because of unsafe employee behavior and a lack of OHS supervision. Unsafe action is an action that can endanger workers or others and can lead to work accidents caused by various things such as not using personal protective equipment (PPE), not following work procedures, not following work safety regulations or not working cautiously (Pratiwi, 2012).

Accidents in a hospital in West Java such as being pricked by a needle $(32.8 \%)$ cut by a knife $(3.3 \%)$, injured (24.5\%), and splashed with blood or other bodily fluids of the patients $(39.4 \%)$, on average, occur in the morning (Ibrahim, Mardiah and Priambodo, 2014). Another Jahangiri et al. (2016) conducted in one of the teaching hospitals in Indonesia states that health workers suffer from injuries from sharp objects, accounting for $48 \%$ and from a splash of bodily fluids, accounting for $62 \%$. The accidents are based on the perception of obstacles to implement universal precaution because of the limited personal protective equipment provided $(73 \%)$ at the hospital's emergency department. Moreover, previous research conducted in a hospital in Shiraz, Iran shows that the prevalence of needle-punctured cases in nurses is $76 \%$, but $60.2 \%$ do not report this because of the tight schedule of health services $(46.7 \%)$ and the perception that the exposure will only have low risk to infection (37.7\%) (Jahangiri et al., 2016).

Based on previous studies, the level of compliance with the use of PPE on nurses in Hajj Hospital in Surabaya is still quite low. It is observed that there are $17.8 \%$ of nurse compliance and $82.2 \%$ of nurse non-compliance in using masks as well as $57.8 \%$ of nurse compliance and $42.2 \%$ of nurse non-compliance in using gloves. The high level of non-compliance in using PPE is because nurses have become accustomed to taking these non-compliant practices and there is no transmission of the feared infection, so the nurses feel safe despite not using PPE. Therefore, it can be concluded that nurses in one of the Hajj Hospitals in Surabaya have a low perception of risk/susceptibility and severity/ seriousness (Yuliana, 2016). 
Perception is defined as a person's view in interpreting and evaluating something (Robbins, 2003). Furthermore, the nurses' perception of personal protective equipment can be defined as the process of adaptation, ways of thinking, evaluation and interpretation of personal protective equipment of nurses using sensory apparatus sensory apparatus that will influence them to behave in compliance with the use of personal protective equipment.

According to the Health Belief Model, one's submissive behavior can be influenced by individual perceptions in taking precautions, which is in accordance with what is generally believed and what is personally believed by the individual him/herself (Rosenstock, 1974). The main concepts that can be used to predict one's behavior in taking precautions in the Health Belief Model are perceived susceptibility, perceived severity, perceived benefits, perceived barriers, and cues to actions. Based on the background that has been described above, it is necessary to conduct research on the relationship between perceptions and compliance in the use of personal protective equipment of the nurses at RSU Haji Surabaya.

\section{METHODS}

This study was an observational and crosssectional study. This research was conducted in October 2019 at RSU Haji Surabaya. The populations in this study were all nurses who served in the inpatient operating room and lung room of the Haji Hospital in Surabaya. The sampling technique in this study was total sampling, accounting for 21 nurses in the operating room and 12 nurses in the lung room. The independent variables in this study were the nurses' characteristics (gender, age and education) and nurses' perceptions. Meanwhile, the dependent variable was compliance with the use of PPE. This study used questionnaires and observation sheets as the instruments to collect the data. Data analysis was performed by looking at the value of contingency coefficients in the data processing software to see the strong or close relationship between the dependent variable and the independent variables.

Research ethics test has been conducted for this study, and this study has obtained an ethical clearance certificate from the ethics committee of the Faculty of Dentistry, Universitas Airlangga Number 353/HRECC.FODM/VI/2019).

\section{RESULTS}

The work of nurses in the inpatient operating room and lung room at RSU Haji Surabaya involves a variety of tasks that have a risk of disease transmission through droplet transmission, airborne transmission, or patients' bodily fluids transmission. The actions of nurses in inpatient operating room and lung room are illustrated in Table 1.

These actions have various risks for the nurses, so personal protective equipment is needed to reduce the risk of disease transmission and work accidents. Personal protective equipment available in the room includes: hands coons, surgical masks, N95 masks, boots, protective gowns / aprons and goggles. The usage of personal protective equipment is adjusted in accordance with the actions taken by the nurses.

\section{Characteristics of the Nurses}

The characteristics of the nurses at RSU Haji Surabaya in this study consistof age, gender, education, and the assignment room, as follows. The results in Table 2 show that there are 10 male respondents (30.3\%), 7 of whom (21.2\%) are from the operating room and 3 of whom $(9.1 \%)$ are from the lung room. Meanwhile, the number of female nurses is 23 respondents $(69.7 \%), 14$ of whom

Table 1. Nurses' Actions in Inpatient Operating Room and Lung Room at RSU Haji Surabaya in 2019

\begin{tabular}{l}
\hline \multicolumn{1}{c}{ Nurses' Action } \\
\hline Measuring vital signs (blood pressure, temperature, pulse \\
and respiration) \\
Administering Oral drugs \\
Installing and removing infusion \\
Replacing the IV fluids \\
Observing and handling urine bags \\
Inserting and removing a catheter \\
Administering injection drugs (iv, im, ic, sc) \\
Drawing blood (iv) \\
Installing oxygen \\
Administering suppository drugs \\
Installing NGT \\
Installing blood transfusion \\
Inspecting sample collection (urine, sputum, etc.) \\
Preparing patients for surgery \\
Giving Wound care \\
Reducing gastric fluid
\end{tabular}


(42.4\%) are from the operating room and 9 of whom $(27.3 \%)$ are from the lung room. Thus, it can be concluded that there are more female than male nurses in both rooms.

Moreover, the results in Table 2 show that there are 17 respondents aged 21-30 years old (51.5\%), 11 of whom $(33.3 \%)$ are from the operating room and 6 of whom (18.2\%) are from the lung room. Meanwhile, the number of nurses aged 31-40 years is 9 respondents $(27.25 \%), 5$ of whom5 (15.15\%) are from the operating room and 4 of whom (12.1\%) are from the lung room. Moreover, the number of nurses aged $>40$ years old is 7 respondents $(21.25 \%), 5$ of whom $(15.15 \%)$ are from the operating room and 2 of whom $(6.1 \%)$ are from the lung room. Thus, it can be concluded that there are more nurses aged 21-30 years than nurses aged $31-40$ years old and $>$ 40 years old.

The results in Table 2 show that in the operating room and lung room are mostly Diploma level 3 with a total of 27 nurses $(81.8 \%), 17$ of whom

Table 2. Distribution of the Nurses' Characteristics in the Inpatient Installation of the Operating Room and Lung Room at RSU Haji Surabaya in 2019

\begin{tabular}{lcccccc}
\hline \multirow{2}{*}{ Characteristic } & \multicolumn{2}{c}{$\begin{array}{c}\text { Operating } \\
\text { Room }\end{array}$} & \multicolumn{2}{c}{$\begin{array}{c}\text { u } \\
\text { Room }\end{array}$} & \multicolumn{2}{c}{ Total } \\
\cline { 2 - 7 } & $\mathbf{n}$ & $\mathbf{\%}$ & $\mathbf{n}$ & $\mathbf{\%}$ & $\mathbf{N}$ & $\mathbf{\%}$ \\
\hline Gender & & & & & & \\
Male & 7 & 21.2 & 3 & 9.1 & 10 & 30.3 \\
Female & 14 & 42.4 & 9 & 27.3 & 23 & 69.7 \\
\hline Age & & & & & & \\
(Years) & & & & & & \\
$21-30$ & 11 & 33.3 & 6 & 18.2 & 17 & 51.5 \\
$31-40$ & 5 & 15.15 & 4 & 12.1 & 9 & 27.25 \\
$>40$ & 5 & 15.15 & 2 & 6.1 & 7 & 21.25 \\
\hline Education & & & & & & \\
D3 & 17 & 51.5 & 10 & 30.3 & 27 & 81.8 \\
Bachelor & 4 & 12.1 & 2 & 6.1 & 6 & 18.2 \\
\hline
\end{tabular}

Table 3. Level of the Nurses' Compliance in the Inpatient Operating Room and Lung Room at RSU Haji Surabaya in 2019

\begin{tabular}{lcccccc}
\hline \multirow{2}{*}{ Compliance } & \multicolumn{2}{c}{$\begin{array}{c}\text { Operating } \\
\text { Room }\end{array}$} & \multicolumn{2}{c}{ Lung Room } & \multicolumn{2}{c}{ Total } \\
\cline { 2 - 7 } & $\mathbf{n}$ & $\mathbf{\%}$ & $\mathbf{n}$ & $\mathbf{\%}$ & $\mathbf{N}$ & $\mathbf{\%}$ \\
\hline Compliant & 3 & 14.3 & 8 & 66.7 & 11 & 33.4 \\
$\begin{array}{l}\text { N o n - } \\
\text { compliant }\end{array}$ & 18 & 85.7 & 4 & 33.3 & 22 & 66.6 \\
\hline
\end{tabular}

$(51.5 \%)$ are from the operating room and 10 of whom $(30.3 \%)$ are from the lung room.

\section{Nurses' Compliance with the Use of PPE}

The results in Table 3 shows that the percentage of non-compliant nurses in using PPE is still high with the number reaches 22 nurses $(66.6 \%), 18$ of whom $(54.54 \%)$ are from the operating room and 4 of whom $(12.1 \%)$ are from the lung room. Moreover, the number of the compliant nurses is 11 nurses $(33.4 \%), 3$ of whom (9.1\%) are from the operating room and 8 of whom $(24.3 \%)$ are from the lung room.

The results in Table 4 about the nurses' compliance based on gender show that $90 \%$ of

Table 4. Nurses' Compliance Level by Gender at RSU Haji Surabaya in 2019

\begin{tabular}{|c|c|c|c|c|c|c|}
\hline \multirow{2}{*}{ Compliance } & \multicolumn{2}{|c|}{ Male } & \multicolumn{2}{|c|}{ Female } & \multicolumn{2}{|c|}{ Total } \\
\hline & $\mathbf{n}$ & $\%$ & n & $\%$ & $\mathbf{N}$ & $\%$ \\
\hline Compliant & 1 & 10 & 10 & 43.4 & 11 & 33.3 \\
\hline $\begin{array}{llll}\mathrm{N} & \mathrm{o} & \mathrm{n} & - \\
\text { compliant }\end{array}$ & 9 & 90 & 13 & 56.6 & 22 & 66.7 \\
\hline
\end{tabular}

Table 5. Perceptions of the Nurses in Using PPE in the Inpatient Operating Room and Lung Room at RSU Haji Surabaya in 2019

\begin{tabular}{lcccccc}
\hline \multirow{2}{*}{ Perceptions } & \multicolumn{2}{c}{$\begin{array}{c}\text { Operating } \\
\text { Room }\end{array}$} & \multicolumn{2}{c}{ Lung Room } & \multicolumn{2}{c}{ Total } \\
\cline { 2 - 7 } & $\mathbf{n}$ & $\mathbf{\%}$ & $\mathbf{n}$ & $\mathbf{\%}$ & $\mathbf{N}$ & $\%$ \\
\hline $\begin{array}{l}\text { Pe r c e iv e d } \\
\text { Susceptibility }\end{array}$ & & & & & & \\
Positive & 20 & 95.2 & 10 & 83.3 & 30 & 90.9 \\
Negative & 1 & 4.8 & 2 & 16.7 & 3 & 9.1 \\
\hline P e r c e iv e d & & & & & & \\
Severity & & & & & & \\
Positive & 21 & 100 & 8 & 66.7 & 29 & 87.9 \\
Negative & 0 & 0 & 4 & 33.3 & 4 & 12.1 \\
\hline P e r c e i v e d & & & & & & \\
Benefits & & & & & & \\
Positive & 19 & 90.5 & 12 & 100 & 31 & 94 \\
Negative & 2 & 9.5 & 0 & 0 & 2 & 6 \\
\hline P e r c e i v e d & & & & & & \\
Barriers & & & & & & \\
Positive & 20 & 95.2 & 12 & 100 & 32 & 97 \\
Negative & 1 & 4.8 & 0 & 0 & 1 & 3 \\
\hline Cues & & & & & & \\
Action & & & & & & \\
Positive & 18 & 85.7 & 11 & 91.7 & 29 & 87.8 \\
Negative & 3 & 14.3 & 1 & 8.3 & 4 & 12.2 \\
\hline
\end{tabular}


male nurses are less compliant with the use of PPE compared to female nurses.

\section{Nurses' Perception in Using PPE Based on the Health Belief Model}

The results in Table 5 show that there are 3 nurses who have negative perceptions of perceived susceptibility $(9.1 \%)$, consisting of 1 nurse $(3 \%)$ from the operating room and 2 nurses $(6.1 \%)$ from the lung room. Most nurses have positive perceptions of the perceived susceptibility, as many as 30 nurses (90.9\%), consisting of 20 nurses $(60.6 \%)$ from the operating room and 10 nurses (30.3\%) from the lung room.

In relation to perceived severity, there are more nurses that have positive perceptions compared to those who have negative perceptions with only 4 nurses $(12.1 \%)$ in the lung room. Meanwhile the number of nurses who have negative perceptions of PPE benefits is 2 nurses (6\%) from the operating room, while 31 nurses $(94 \%)$ of nurses have positive perceptions of the benefits of using PPE.

Furthermore, the results show that the number of nurses who have negative perceptions of perceived barriers when using PPE is only 1 nurse (3\%) from the operating room. In contrast, the number of nurses who have positive perceptions is 32 nurses (97\%). In cues to action results, it shows that the number of nurses who have negative perceptions is fewer,

Table 6. Relationship between the Nurses' Characteristics and Compliance with the use of PPE at RSU Haji Surabaya

\begin{tabular}{lc}
\hline \multirow{2}{*}{ Nurses' Characteristics } & Compliance \\
\cline { 2 - 2 } & Coefficients Contingency (C) \\
\hline Gender & 0.310 \\
Age & 0.280 \\
Education & 0.164 \\
\hline
\end{tabular}

Table 7. Relationship between the Nurses' Perception and Compliance with the use of PPE at RSU Haji Surabaya

\begin{tabular}{lc}
\hline \multirow{1}{*}{ Nurses' Perception } & \multicolumn{1}{c}{ Compliance } \\
\cline { 2 - 2 } & Coefficients Contingency (C) \\
\hline Susceptibility & 0.18 \\
Severity & 0.312 \\
Benefits & 0.089 \\
Barriers & 0.124 \\
Cues to Action & 0.066 \\
\hline
\end{tabular}

accounting for 4 nurses (12.2\%); 3 nurses (9.1\%) are from the operating room and 1 nurse $(3.1 \%)$ is from the lung room.

\section{Correlation between the Nurses' Characteristics and Compliance with the use of PPE at RSU Haji Surabaya}

Based on the results in Table 6, it can be seen that the relationship between gender variable and compliance with the use of PPE has the highest connection with coefficients contingency (C) of 0.310 , whereas education has the lowest connection with coefficients contingency $(C)$ of 0.164 .

\section{Correlation between the Nurses' Perception and Compliance with the use of PPE at RSU Haji Surabaya}

Based on the statistical test results in Table 7, the coefficients contingency (C) of perceived severity reaches 0.312 , which means it has the strongest relationship with the nurses' compliance in using personal protective equipment compared to the other four perceptions.

\section{DISCUSSION}

Nurses' compliance in using PPE in this study is measured based on observations on nurses' actions. Based on the observations, it is known that the nurses have complied with the use of PPE but there are still some shortcomings. Personal protective equipment that is often used in the operating room is surgical masks and medical gloves, while personal protective equipment that is rarely used are protective gowns / aprons, protective shoes and goggles. In addition, the nurses use masks not for one medical action, but for one work shift. Meanwhile, personal protective equipment that is frequently used in the lung room is surgical masks, N95 masks, medical gloves and aprons. Protective shoes and goggles are PPE that is rarely used in the lung room. N95 masks and surgical masks are also not used for one medical action, but for one work shift. This condition will increase the risk of transmission of diseases in the hospital. A non-optimal use of PPE is caused by the poor habits of nurses and PPE availability.

Differences in the level of compliance of nurses in the lung room and operating room can be caused by different levels of risks. In the lung room, the level of risk of transmission of infectious diseases (lung diseases) can occur in a variety of transmissions, especially airborne transmission and 
droplets. Meanwhile, the level of risk of disease transmission in the operating room is lower as the transmission can occur mainly through the transmission of patients' bodily fluids.

Previous studies have shown that health workers who have a higher risk perception of infection are more likely to always adhere to universal precaution standards than those who have a lower risk perception. The study also explains that the higher the perceptions of health workers, the higher the level of compliance (Haile, Engeda and Abdo, 2017). This result is supported by the study done by Risita (2017), stating that there is a significant relationship between risk tolerance and compliance with the use of PPE ( $p$ value 0.044). The risk tolerance is the ability of workers to accept the risks of hazards in their work environment (Risita, 2017).

Henceforth, if the room is considered to have a lower level of risk, then the level of nurse compliance in the room will also be low. Other factors assumed to be the causes of low compliance are the misunderstanding of PPE and inadequate knowledge, which result in a lack of knowledge of the functions and usefulness of PPE.

\section{The Characteristics of the Nurses}

The characteristics of the respondents in this study include gender, age and level of education. In Table 6, it can be seen that the gender variable has a closer relationship with the PPE compliance level than the age variable and the nurses' education variable. The frequency distribution of males workers is lower than their female counterparts, yet 9 out of 10 male nurses are less compliant in using PPE. This is in line with previous research conducted by Zubaidah, Arifin and Jaya (2015) at Pelita Insani Hospital in Banjarmasin which suggests that $62.07 \%$ of the nurses who are not compliant in wearing PPE in hospitals are mainly males $(66.67 \%)$.

Moreover, the age variable has a lower relationship with the PPE compliance level. This is in line with previous research that states that there is no meaningful relationship between age and nurses' behavior in maintaining their safety (Mahdarsari, Handiyani and Pujasari, 2016). The result of this study is also in accordance with Yulita and Handiyani (2013) study that states that there is no significant relationship $(p=0.572)$ between the age variable of nurses and the behavior of nurses in maintaining the safety to biological agents. Moreover, it is also known that biological hazards in hospitals consist of microorganisms both bacterial or viral pathogens that can infect humans through the intermediary of blood, fluids, air, and droplets (Yulita and Handiyani, 2013). The result is also consistent with the theory stating that age influences a person's behavior, but it is not directly related to compliance in PPE usage. However, there are other factors that might encourage nurses to use PPE, both originating from internal or external factors. In principle, the increase of age will increase one's maturity and more information absorption that will affect behavior (Wibowo, Suryani and Sayono, 2013).

The education variable, has the lowest contingency coefficient value. This shows that education has a weak relationship with the nurses' compliance in using PPE. The high level of one's education does not guarantee one's compliance with the use of PPE. This is in line with a Mahdarsari, Handiyani and Pujasari (2016) study which states that there is no meaningful relationship between the level of education and the behavior of nurses in maintaining personal safety, namely physical, biological, chemical, ergonomic and psychological hazards. In fact, maintaining personal safety from biological hazards can be done by using personal protective equipment while the nurse is on duty (Mahdarsari, Handiyani and Pujasari, 2016). The research is in accordance with the theory put forward by Carpenito (2013) that the level of education can increase compliance if it is an active education that is obtained independently and goes through certain stages.

\section{Nurses' Perception in Using PPE}

Health Belief Model is a theory developed in 1950 by social psychologists at the United States Community Health Services. This theory has developed from two sources, namely the Stimulus Response (S-R) Theory and Cognitive Theory which state that habits affect individual expectations of certain situations including pain-related voidance or health expectations. It is hope that certain health actions can prevent pain.

According to Janz and Becker (1984), Health Belief Model consists of 5 key concepts, namely perceptions of susceptibility, severity, benefits, barriers, and cues to action, which are used in this study as independent variables to see perceptions of the use of personal protective equipment (Janz and Backer, 1984).

Personal protective equipment is defined as a tool used to protect workers from injury or diseases caused by contact with hazards in the workplace, 
whether chemical, biological, , physical, electrical, and mechanical hazards as well as radiation (Occupational Health and Safety Management Systems, 2007). Personal protective equipment becomes the main component of personal precaution, and it is commonly used by workers, especially nurses as a standard precaution in taking actions (Minister of Manpower and Transmigration of the Republic of Indonesia 2010).

\section{Perceived Susceptibility}

Based on the results of the study, nurses' compliance in using PPE does not have a close relationship with the perceived susceptibility. Previous research conducted by Laranova, Afriandi, and Pratiwi (2018) shows that there is no significant relationship between health personnel perceptions of hazards / risk exposure in hospitals and the use of personal protective equipment $(p=0.023)$. Knowledge of the risk of exposure to various hazards during work helps individuals in taking certain actions, but there are still health workers who do not concern with it because they think it is not important, or they do not understand the procedures that must be performed (Chia et al., 2005). Another research also shows that there is no influence between perceived vulnerability and the behavior of wearing PPE (protective glasses) (Sakinah, 2018).

The results of these studies are in accordance with Notoatmodjo's statement (2012), suggesting that although one's level of health awareness is high, the practice of one's healthy behavior might still be low. Even though the respondents have already had a good perceived susceptibility, it is not certain whether or not someone is wearing personal protective equipment as his preventative measure (Notoatmodjo, 2012).

The perceived susceptibility is related to risk. Therefore, if someone tries to prevent himself from a disease, it can be said that he must know that he is vulnerable to possible risks (Glanz, Rimer and Viswanath, 2008). This can encourage him to take preventative actions as preventive actions will be taken if someone knows that he is at risk. Risk perception that occurs can have an impact on a person's health behavior towards safety such as the behavior of using PPE (Hayden, 2014).

\section{Perceived Severity}

The relationship between the performance of the nurses' PPE usage and the nurses' perceptions of severity has the greatest value among the 4 other perceptions, but the value $<0.5$ means that nurses' compliance in using PPE has a weak relationship with the perception of perceived severity.

This is in accordance with Bosch et al. (2010) research which states that perceived severity has no influence on the behavior of using personal protective equipment to avoid possible risks. In the study conducted by Sakinah (2018), perceived severity does not have a significant effect on the compliance with the use of personal protective equipment .

Perceived severity is a belief about the impact of severity that is obtained by someone when he is exposed to a disease or left untreated (Glanz, Rimer and Viswanath, 2008). A person will not change his behavior unless he feels the consequences are severe. If the consequences received can still be tolerated, then one's behavior tends not to change. Individual perception about the seriousness and severity of an illness that they will be suffered from, if not using personal protective equipment, will encourage someone to take preventative behaviors. The more serious a disease that someone will suffer, the greater the person's actions in prevention.

\section{Perceived Benefits}

Based on the results of the study, nurses' compliance with the use of PPE has a weak relationship with the perceived benefits, or the relationship can be ignored because the coefficient contingency value is very small. The result of the study is also supported by previous research conducted by Sakinah (2018) that there is no influence between perceived benefits and the behavior of using personal protective equipment (protective glasses) .

The result is also in line with what Hochbaum (1958) says that although perceived benefits are sufficient, it is still unclear that the level of perceived benefits can make someone do prevention behaviors (Hochbaum, 1958). In this study, although $94 \%$ of nurses have positive perceptions of the benefits of using PPE, it does not affect the level of compliance of nurses in using PPE.

\section{Perceived Barriers}

Based on the results of the study, nurses' compliance with the use of PPE does not have a close relationship with the perception of perceived barriers. This is in accordance with previous research 
conducted by Laranova, Afriandi, and Pratiwi (2018) which states that there is no correlation between the perceived barriers in the use of personal protective equipment with workplace accidents $(\mathrm{r}=-0.149$, $\mathrm{p}=0.136)$ 8). Another research done by Jahangiri et al. (2016) also shows that the perceived barriers to the implementation of universal precaution is equivalent to the low supply of personal protective equipment in hospitals. Perceived obstacles are found when nurses taking certain actions such as the personal protective equipment find it uncomfortable, inconvenient, painful or time-consuming to use (Glanz, Rimer and Viswanath, 2008). For example, nurses do not use gloves or handscoons when drawing blood from patients because they feel they are wasting time while wearing them.

Based on the theory by Niven (2008), noncompliance of health workers with the use of PPE can be influenced by the inconvenience of workers in using PPE during work such as heat, tightness, and illness, among many others. Perception of danger or level of risk is connected to the way the nurses feel that the work is not dangerous or has an impact on their health, especially for nurses who have been doing the work for years.

\section{Cues to Actions}

The results of the study show that nurses' compliance with the use of PPE has a weak relationship with cues to action, or the relationship can be ignored because the contingency coefficient value is very small. Cues to action is a trigger for action or one of the strategies to get information in encouraging someone to behave well, in the form of external factors such as messages to the mass media oradvice from colleagues (Conner and Norman, 2005).

This study is in accordance with a previous study which states that the mass media ( $p$ value $=0.677)$ and coworkers $(\mathrm{p}$ value $=0.137$ ) have no significant effect on the compliance of surgical nurses with the use of PPE (Sudarmo, Helmi and Marlinae, 2016). This is also consistent with what is stated by Mahdarsari, Handiyani and Pujasari (2016) that the presence or absence of co-workers who use PPE when performing childbirth assistance affects them in using PPE.

Moreover, Sakinah (2018) in his research states that messages from the media and advice from others are external factors that can affect someone in accepting perceived severity, so it will indirectly affect one's compliance behavior

\section{CONCLUSION}

To conclude, the variables that have the closest relationship with the compliance of personal protective equipment usage are gender and perceived severity. Moreover, age, education, perceived susceptibility, perceived benefits, perceived barriers and cues to action have a small coefficient contingency value, so they do not have a close relationship with the compliance variable in using personal protective equipment, or the relationship can be ignored.

\section{ACKNOWLEDGEMENTS}

This study was conducted independently with internal funding coming from the researchers themselves. I thank all parties who have helped in the conduct of this research, namely all respondents, RSU Haji Surabaya.

\section{REFERENCES}

Bosch, A. et al. (2010) 'Zoonotic Disease Risk Perception and Use of Personal Protective Measures among Wildlife Biologists : An Application of the Health Belief Model', Human Dimensions of Wildlife, 15(3), pp. 221-228.

Chia, S. E. et al. (2005) 'Appropriate use of personal protective equipment among healthcare workers in public sector hospitals and primary healthcare polyclinics during the SARS outbreak in Singapore', Occupational Environment Medicine, 62(7), pp. 473-477.

Conner, M. and Norman, P. (2005) Predicting Health Behaviour. USA: Open University Press.

Glanz, K., Rimer, B. K., and Viswanath, K. (2008) Helath Behavior and Health Education. United States of America: Jossey-Bass.

Haile, T. G., Engeda, E. H. and Abdo, A. A. (2017) 'Compliance with Standard Precautions and Associated Factors among Healthcare Workers in Gondar University Comprehensive Specialized Hospital, Northwest Ethiopia', Journal of Environmental and Public Health, 2017(2),pp. 1-8.

Hayden, J. (2014) Health Behavior Theory. 2nd edn. USA: Jones \& Bartlett Learning Publications.

Hochbaum, G. M. (1958) Public Participation in Medical Screening Programs : A SocioPsychological Study, Public Health Service Publication. Washington, DC: US. Goverment Printing Office. 
Ibrahim, K., Mardiah, W. and Priambodo, A. P. (2014) 'Pengetahuan, Sikap, dan Praktik Kewaspadaan Universal Perawat Terhadap Penularan HIV/ AIDS', Jurnal NERS, 9(1), pp. 11-18.

Jahangiri, M. et al. (2016) 'Needle Stick Injuries and their Related Safety Measures among Nurses in a University Hospital, Shiraz, Iran', Safety and Health at Work. 7(1), pp. 72-77.

Janz, N. K. and Backer, M. H. (1984) 'Observations on the reproductive biology of the angular rough shark, Oxynotus centrina (Oxynotidae)', in Health Education Quartely,11(1), pp. 1-47.

Carpenito, L. J. (2013) Diagnosa Keperawatan: Aplikasi pada Praktek Klinik(Terjemahan). Edisi 6. Edisi 6. Jakarta: EGC.

Laranova, A., Afriandi, I. and Pratiwi, Y. S. (2018) 'Persepsi Tenaga Kesehatan terhadap Penggunaan Alat Pelindung Diri dan Kejadian Kecelakaan Akibat Kerja di Salah Satu Rumah Sakit di Kota Bandung, Jurnal Sistem Kesehatan, 3(4), pp. 189-197.

Mahdarsari, M., Handiyani, H. and Pujasari, H. (2016) 'Peningkatan Keselamatan Diri Perawat melalui Optimalisasi Fungsi Manajemen', Jurnal Keperawatan Indonesia, 19(3), pp. 176-183.

Ministry of Manpower and Transmigration (2010). PER.08.MEN/VII/2011 Tentang Alat Pelindung Diri. Jakarta:Ministry of Manpower and Transmigration

National Safety Council (2013) Injury Facts, 2013 Edition. USA.

Niven, N. (2008) Psikologi Kesehatan : Pengantar Untuk Perawat Dan Profesional. Jakarta: EGC.

Notoatmodjo, S. (2012) Promosi Kesehatan dan Perilaku Kesehatan. Jakarta: PT Rineka Cipta.

Occupational Health and Safety Management Systems (2007) Sistem Manajemen Keselamatan Dan Kesehatan Kerja Persyaratan, Occupational Health and Safety Management Systems.England: OHSAS Project Group 2007

Pratiwi, A. D. (2012) Analisi Faktor-faktor yang Mempengaruhi Tindakan Tidak Aman (Unsafe Act) pada Pekerja di PT X Tahun 2011. Thesis: Faculty of Public Health, Universitas Indonesia.

Risita, E. (2017) Hubungan Persepsi tentang Risiko dan Alat Pelindung Diri serta Toleransi Risiko
Pekerja dengan Kepatuhan Penggunaan Alat Pelindung Diri di Proyek Konstruksi Mass Rapid Transit Jakarta Tokyu Wika Joint Operation. Thesis: Faculty of Medicine and Health Sciences, Syarif Hidayatullah State Islamic University.

Robbins, S. P. (2003) Perilaku Organisasi. Jakarta: Index.

Rosenstock, I. M. (1974) 'Historical origins of the health belief model. Health Education Monographs', in Health Education Monographs, 2(4), pp. 328-335.

Sakinah, Z. V. (2017) 'Aplikasi Health Belief Model Dalam Menganalisis Perilaku Penggunaan Kacamata Pelindung', Jurnal PROMKES, 5(1), pp. 105-116.

Sudarmo, Helmi, Z. N. and Marlinae, L. (2016) 'Perilaku Terhadap Kepatuhan Penggunaan Alat Pelindung Diri (APD) Untuk Pencegahan Penyakit', Jurnal Berkala Kesehatan, 2(1), pp. $27-44$.

Uhud, A. et al. (2008) Buku Pedoman Pelaksanaan Kesehatan dan Keselamatan Kerja Untuk Praktek dan Praktikum. Surabaya: Fakultas Kedokteran Gigi Universitas Airlangga.

Wibowo, A., Suryani, M. and Sayono (2013) 'Hubungan Karakteristik Perawat Dengan Penggunaan Sarung Tangan Pada Tindakan Invasif di Ruang Rawat Inap RSUD Dr. H. Soewondo Kendal', Jurnal Ilmu Keperawatan dan Kebidanan, 1(4), pp.1-9.

Yuliana, L. (2016) Analisis Faktor yang Berhubungan dengan Perilaku Patuh dalam Penggunaan Alat Pelindung Diri (APD). Thesis: Faculty of Public Health, Universitas Airlangga

Yulita, Y. and Handiyani, H. (2013) The Influence of Reflektif Interaktif Supervision to Behaviors Nurse Safety at Biologic Agent Hazard in RSUD Provinsi Kepulauan Riau Tanjung Uban, Thesis: Faculty of Nursing, Indonesia University

Zubaidah, T., Arifin, A. and Jaya, Y. A. (2015) 'Pemakaian Alat Pelindung Diri Pada Tenaga Perawat Dan Bidan Di Rumah Sakit Pelita Insani', Jurnal Kesehatan Lingkungan: Jurnal dan Aplikasi Teknik Kesehatan Lingkungan, 12(2), pp. 291-298. 